\title{
SIZE AND IMPLICATION OF UNDERGROUND ECONOMY IN ROMANIA - A MIMIC APPROACH
}

\author{
Corina-Maria Ene ${ }^{1}$ \\ Andrei Ștefänescu
}

\begin{abstract}
Since the economic crisis affected the real economy in Romania, the official GDP declined by almost 5 percent in 2009 compared with 2008, 1.3 percent in 2010 against the previous year and unemployment increased too. In 2011 a moderate growth of the GDP is expected but unemployment will further increase. Against this background the extent of the underground economy in Romania and its development over time are once again the subject of intense debate, as many people will attempt to make up for loss of income in the official economy through greater participation in the underground economy.

The objective of this paper is to estimate the size of the underground economy in Romania by using the Multiple Indicators Multiple Causes (MIMIC) method. The MIMIC approach is based on the idea that the underground economy is not a directly observable measure, but it is possible to approximate it using quantitatively measurable causes of working in the underground economy and using indicators in which underground economic activities are reflected. In addition, the paper aims at clarifying to what extent the variables explain the size of the underground economy in Romania.
\end{abstract}

Key words: underground economy, Multiple Indicators Multiple Causes (MIMIC), latent variable, structural equation model

JEL Codes: O17, $H 26$

\section{Introduction}

Underground economy exists and it has been investigated in various studies. The problem is not to demonstrate this assertion, but to evidence the size and dynamic of this sector and to design economic policy measures in order to reduce its proliferation.

As a result of the economic crisis, all European countries are again expected to face a renewed increase in the size of the underground economy for the second time in 2010 (first time in 2009). In spite of all, it seems that the size of the underground economy has risen in Romania over the last decade too, but the growth rate in Romania has been much higher than in other European countries, narrowing the gap that initially existed between Romania and these countries.

To this extent, the purpose of this paper is to further improve estimates of the size and scope of the underground economy in Romania by applying the MIMIC (Multiple Indicators, Multiple Causes) approach.

The remainder of this paper is organized as follows. The next section introduces the MIMIC methodology and the third section offers some estimation results. Concluding remarks are provided in last section.

\footnotetext{
${ }^{1}$ Hyperion University from Bucharest, Faculty of Economic Sciences, Romania, e-mail: corina.maria.ene@gmail.com

2 "1 Decembrie 1918" University of Alba Iulia, Faculty of Science, Romania, e-mail: andrei_stanescu2003@yahoo.com
} 


\section{MIMIC Methodology}

By definition, the underground economy can not be directly observed. As a result, its size should be only estimated. In this context, a very complex approach is used and it is known as "structural equation" or MIMIC model.

Generally, structural equation model requires evidence of statistical relationships that occur between a latent variable (unobserved) and several observed variables. The MIMIC approach allows several indicator variables and several causal variables in forming structural relationships to explain a latent variable, in our case, the size of the underground economy.

This method - taken from the psychometrics science - was applied in the economics (as a latent variable model) by Zellner (1970) and Goldberger (1972) for the first time. The first application of the model in order to estimate the underground economy belongs to Frey and WeckHannemann (1984), which have processed 17 developed countries data. The idea was taken by Aigner, Schneider and Ghosh (1988). They improved the method by adjusting it in order to capture the dynamics of the investigated phenomenon (DYMIMIC) and applied it to U.S. data. Giles (1999, 2002) developed the method based on a complex time series econometric analysis and estimated the hidden economy in New Zealand and Canada. Some other important studies were published by Bajada and Schneider (2005) for Australia and other Pacific countries, dell'Anno and Schneider (2003) for the Italian economy, Schneider (2005, 2007 and 2010) for countries groups etc.

MIMIC is a structural and an econometric model that treats the underground economy size as a "latent unobserved variable" that links a collection of observable indicators - reflecting changes in underground economy size - with causal observed variables - considered to be the driving forces behind underground economy activities. Given appropriate data and indicators, estimates can be achieved by standard econometric procedures.

Structural equations model shows the causal relationships between unobserved variables which are presumed to be influenced by the size-dependent underground economy indicators. The identified structural dependence allows forecasting future growth and size of the underground sector. Interaction between the causes, structural economy and indicators is shown in Figure no.1.

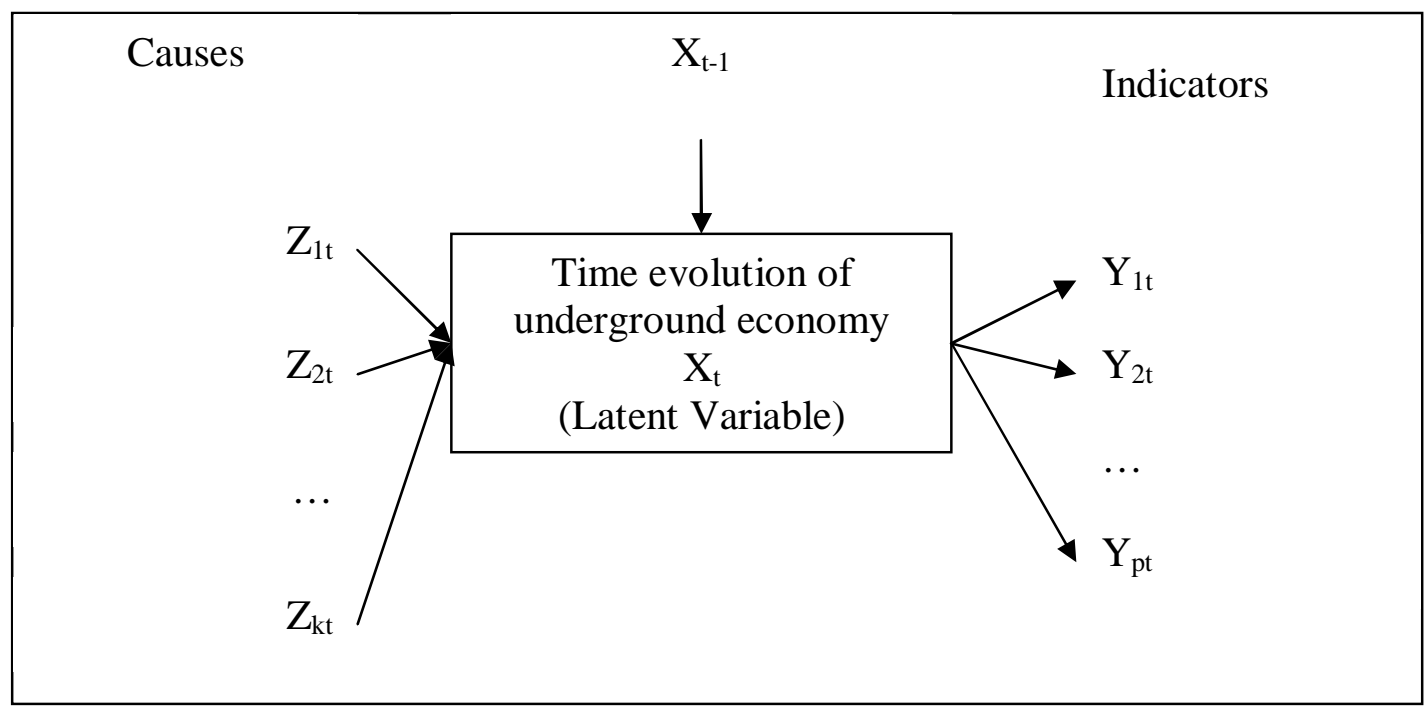

Figure no.1. General structure of MIMIC model (Schneider, 2005)

Generally, MIMIC involves two stages:

1. Creating links between the unobserved variables (or latent) and observed indicators; variables.

2. Writing structural equation model specifying the causal relationships between unnoticed 
In this case, one variable is unobserved (or latent), the size of the underground economy. It is indirectly observed through some indicators that capture the structural dependence of the underground economy by using variables which predict its size and structural changes.

MIMIC consists of two types of equations: a structural one and a measurement equation. The equation which links the latent variable $(\eta)$ and causes $\left(X_{q}\right)$ is named "structural model". The equation revealing the connection between indicators $\left(\mathrm{Y}_{\mathrm{p}}\right)$ and latent variable is named "measuring model".

Therefore, the shadow economy $(\eta)$ is linear determined by exogenous causes $\left(x_{1}, x_{2}, \ldots, x_{p}\right)$ and the likelihood of errors $(\xi)$ it has to be added to:

$$
\eta=\gamma_{1} x_{1}+\gamma_{2} x_{2}+\ldots+\gamma_{q} x_{q}+\xi
$$

Latent variable is subject of some errors $(\varepsilon)$ generated by observable endogenous indicators (y):

$$
\begin{aligned}
& \mathrm{y}_{1}=\lambda_{1} \eta+\varepsilon_{1} \\
& \mathrm{y}_{2}=\lambda_{2} \eta+\varepsilon_{2} \\
& \ldots \ldots \ldots \ldots \ldots \ldots . . . \\
& \mathrm{y}_{\mathrm{p}}=\lambda_{\mathrm{p}} \eta+\varepsilon_{\mathrm{p}}
\end{aligned}
$$

Structural error $(\xi)$ and the measurement errors $(\varepsilon)$ have a normal distribution, and all variables are assumed to zero deviation.

MIMIC uses the following vectors:

$\mathrm{x}^{\prime}=\left(\mathrm{x}_{1}, \mathrm{x}_{2}, \ldots, \mathrm{x}_{\mathrm{q}}\right) \quad$ - observable exogenous causes;

$\gamma^{\prime}=\left(\gamma_{1}, \gamma_{2}, \ldots, \gamma_{\mathrm{q}}\right) \quad$ - structural parameters (structural model);

$\mathrm{y}^{\prime}=\left(\mathrm{y}_{1}, \mathrm{y}_{2}, \ldots, \mathrm{y}_{\mathrm{p}}\right) \quad$ - observable endogenous indicators;

$\lambda^{\prime}=\left(\lambda_{1}, \lambda_{2}, \ldots, \lambda_{\mathrm{p}}\right) \quad$ - structural parameters (measurement model);

$\varepsilon^{\prime}=\left(\varepsilon_{1}, \varepsilon_{2}, \ldots, \varepsilon_{\mathrm{p}}\right) \quad$ - measurement errors;

$v^{\prime}=\left(v_{1}, v_{2}, \ldots, v_{p}\right) \quad$ - standard deviation.

Equations (1) and (2) could be written as:

$$
\begin{gathered}
\eta=\gamma^{\prime} x+\xi \\
\mathrm{y}=\lambda \eta+\varepsilon
\end{gathered}
$$

Assuming $\mathrm{E}\left(\xi^{\prime}\right)=0$ and defining $\mathrm{E}\left(\xi^{2}\right)=\sigma^{2}$ and $\mathrm{E}\left(\varepsilon \varepsilon^{\prime}\right)=\Theta^{2}$, where $\Theta$ is the matrix $v$ diagonal, the model can be reduced to a function of observable variables:

$$
\mathrm{y}=\lambda\left(\gamma^{\prime} x+\xi\right)+\varepsilon=\Pi^{\prime} x+\mathrm{v}
$$

Matrix coefficients and the vector of errors are:

$$
\Pi=\gamma \lambda \lambda^{\prime} \text { and } \mathrm{v}=\lambda \xi+\varepsilon
$$

The obtained covariance matrix is:

$$
\Sigma=\mathrm{E}\left(\mathrm{vv}^{\prime}\right)=\sigma^{2} \lambda \lambda^{\prime}+\Theta^{2}
$$

There are imposed some necessary, but not sufficient conditions to make the model easy to understand. I refer here to so-called "t-rule" which assumes that the number of no redundant elements from observable variables covariance matrix must be greater or equal to the number of 
unknown model parameters, assumed by covariance matrix. A sufficient condition is at least two indicators and one cause, which allows creating a scale for $\eta$. In order to fix a latent variable scale, parameter $\lambda$ is required to be set as an exogenous amount. However, the most important criticism of this model is the dependence of the scalar coefficient $\lambda$ election. Criticism is mainly due to difficulties in determining the exact amount of structural parameters.

There is an important literature regarding the possible causes and indicators of underground economy. The economic process nature allows following distinct categories:

Causes: (a) direct and indirect taxation (current and forecasted): tax increase is a very powerful motivation to engage in underground sector work, (2) regulation intensity: number of laws, their inconsistency and contradictory provisions facilitate the transfer of activities and jobs in the underground sector, (3) the citizens attitude towards state and tax morality principles.

Indicators:

- Monetary indicators: an increase of underground sector activities generates an additional increase of monetary transactions.

- Labour market indicators: increasing labour participation in the underground sector activities is reflected by a reduction of labour participation rate in the formal economy.

- Output indicators: underground economy growth involves inputs transfer (especially labour) from official to unofficial sector, with negative effects on the formal economic growth rate.

These variables selection could be considered ad-hoc. GDP growth rate is one of the international model indicators because it is considered that any change in the underground economy size is reflected by the real GDP growth rate. Real income per capita is an indicator that does not include distortions which occur in the monetary aggregates evaluation, while the share of personal expenditures on goods and services in disposable income is most pertinent in revealing a behavioural indicator assuming that informal income will not be saved, but spent. Generally, causal variables are selected according to each country economy features, their statistical importance and specificity.

\section{Estimation Results for Underground Economy in Romania}

The initiated MIMIC approach uses Romanian economy annual time series for the period 1990-2009. A special attention was paid to data stationary tests.

Romanian annual time series were tested on unit root in levels and differences using Augmented Dickey-Fuller (ADF) and Phillips-Perron (PP) tests. A greater than 0.05 returned value indicates non-stationary time series. Non-stationary analysis revealed the variables considered both causes and indicators are integrated of first order.

Based on previous theoretical considerations, the general model I have proposed (Figure 2) uses the following causal variables:

- $\mathrm{X}_{1}$ : tax burden;

- $\mathrm{X}_{2}$ : corruption index;

- $\mathrm{X}_{3}$ : direct taxes share in GDP;

- $\mathrm{X}_{4}$ : indirect taxes share in GDP;

- $\mathrm{X}_{5}$ : GDP per capita (USD), index calculated;

- $\mathrm{X}_{6}$ : the official unemployment rate;

- $\mathrm{X}_{7}$ : net investments share in GDP.

The model incorporates the following indicators:

- $\mathrm{Y}_{1}$ : population activity rate;

- $\mathrm{Y}_{2}$ : real GDP index;

- $\mathrm{Y}_{3}$ : M1 share in M2.

Tax burden is the major cause of tax evasion. Moreover, an increase of tax rates is a sufficient motivation for moonlighting. Tax burden was calculated as share of all general consolidated budget tax levies in GDP. In order to test whether all components have the same tax 
burden on the economy, this indicator has been split into other indicators (the share of direct taxes in GDP and the share of indirect taxes in GDP). Romania theoretical analysis performed on data recorded during 1990 to 2009 reveals that indirect taxes are most exposed, a high level of tax evasion occurring into this area.

To highlight citizens perceive on bureaucracy and corruption, the model includes corruption perception index published by Transparency International in the Reports on the Global Corruption Barometer. This index denotes a value between 1 and 5 (1 meaning no corruption, 5 meaning a corrupt economic and social environment). We estimate a positive relationship between corruption index and underground economy because it influences the citizens' attitudes towards state and its institutions. A high level of this index will determine the orientation towards the underground economy.

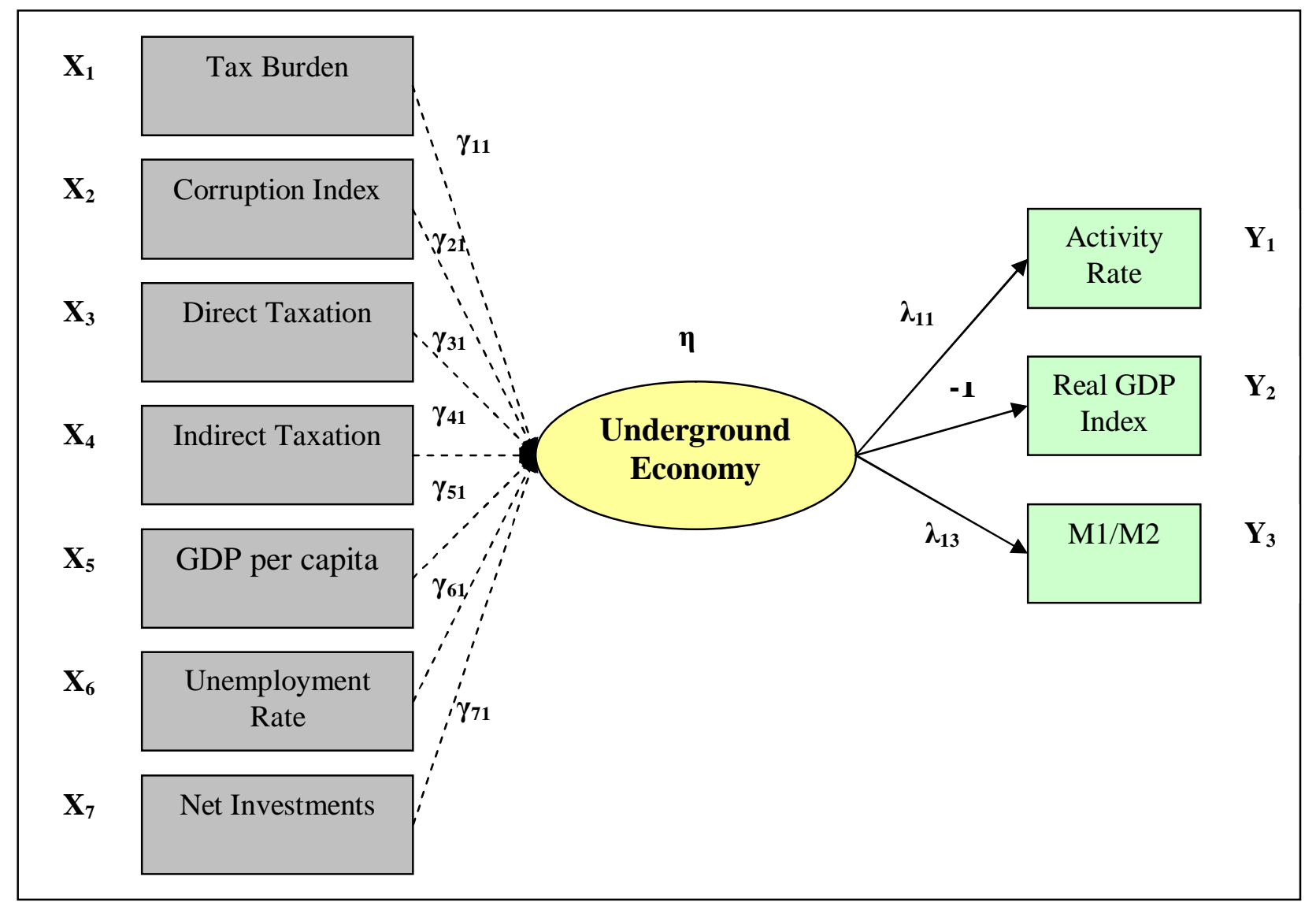

Figure no. 2. General model (MIMIC 7-1-3)

Source: own vision of model

Reduction of GDP per capita is another cause of underground economy. This variable negative sign is based on assumption that a reduction of this indicator indicates a growth of GDP per capita in underground economy.

The relationship between unemployment rate and underground economy is somewhat ambiguous. On the one hand, an increase in official unemployment rate could lead to an increase of informal employment. This reflects a positive relationship between unemployment and underground economy. On the other hand, if we take into account the components of unemployed and informal employment (pensioners, immigrants, etc.), but also people who have both a formal and informal job, this context creates a very shaky correlation between the official unemployment rate and the underground economy. The empirical analysis of available data in Romania suggests a negative statistical relationship between official unemployment rate and underground economy, which 
means that there are frequent cases of individuals who have a formal job, but an informal too, being cash "envelope" paid, a prevailing situation in Romania.

In terms of investments share in GDP, data suggest a positive relation between net investments and underground economy.

Many authors estimated the underground economy based on population activity rate changes. Although empirical data appears as a weak indicator, it was tested. This rate was calculated as a percentage of total civilian employed in 18-64 population aged. However, a population activity rate reduction or low recorded values may suggest a movement of workers from the formal to informal sector. We consider that the positive sign of population activity rate means that labour is underground economy part only in recession periods and the negative sign suggests a steady labour stream between the formal and underground sectors.

The real GDP index position in the model is essential because it is considered fixed, a reference for estimating the rest of parameters. Fixed parameter value is arbitrary (1 or -1$)$, but according to this choice the relative magnitude of the other indicators is determined. We have chosen the value $\lambda=-1$ because we considered that an increase in underground economy has a negative impact on official GDP growth rate. Changing the coefficient sign influences the other indicators sign, but their absolute value is preserved.

The last variable indicates the share of M1 monetary aggregate in M2. This variable incorporates the premise that underground economy transactions are primarily conducted through cash payment or other similar means in order to avoid inspection bodies.

The best model identification starts from a general model (in our case MIMIC 7-1-3) and continues by removing whose variables which structural parameters are not statistically significant. The general model proposed is shown in Figure 2.

The structural equation models results are estimated by maximum likelihood method, using LISREL 8.8 Student version package provided by Scientific Software International. Data are presented in Table 1. $\gamma$ coefficients estimation (corresponding to causal variables) represents $\eta$ estimation basis for each year of the reviewed period. The coefficient corresponding to real GDP index indicator is set to $-1\left(\lambda_{12}=-1\right)$. As we mentioned, it highlights the inverse relationship between official and underground economy.

Results showed in Table 1 present a mainly negative relationship between underground economy size and direct taxation, but positive in relation with indirect taxation. Unemployment rate is the only causal variable in all MIMIC models having negative significance. GDP per capita index has also a negative meaning. Overall tax burden and investment appear not to be statistically significant. Certainly, many of considered variables are loosing their meaning if they are individually analysed.

Following the statistically significant structural parameters we conclude that the main causes of the underground economy in Romania are: unemployment rate, direct and indirect taxation, changes in GDP per capita and corruption. Starting from the general model and eliminate statistically insignificant variables, we consider MIMIC 5-1-2c the best model. Its structure is shown in Figure 3 (as it appears after processing using LISREL software). 
MIMIC estimation results for Romania

Table no. 1.

\begin{tabular}{|c|c|c|c|c|c|c|c|c|c|c|c|c|c|}
\hline & $\begin{array}{c}\text { Tax } \\
\text { Burden }\end{array}$ & $\begin{array}{l}\text { Corrupti } \\
\text { on Index }\end{array}$ & $\begin{array}{c}\text { Share of } \\
\text { direct } \\
\text { taxation } \\
\text { in GDP }\end{array}$ & $\begin{array}{l}\text { Share of } \\
\text { indirect } \\
\text { taxation } \\
\text { in GDP }\end{array}$ & $\begin{array}{c}\text { GDP per } \\
\text { capita } \\
\text { (Index) }\end{array}$ & $\begin{array}{c}\text { Unemplo } \\
\text { yment } \\
\text { Rate }\end{array}$ & $\begin{array}{c}\text { Net } \\
\text { Investme } \\
\text { nts Rate }\end{array}$ & $\begin{array}{l}\text { Populati } \\
\text { on } \\
\text { Activity } \\
\text { Rate }\end{array}$ & $\begin{array}{l}\text { Share } \\
\text { of M1 } \\
\text { in M2 }\end{array}$ & $\begin{array}{c}\text { Chi- } \\
\text { square } \\
\text { (p-value) }\end{array}$ & $\begin{array}{l}\text { RMSEA } \\
\text { (p-value) }\end{array}$ & AGFI & Df \\
\hline & $\mathbf{X}_{1}$ & $\mathbf{X}_{2}$ & $\mathbf{X}_{\mathbf{3}}$ & $\mathbf{X}_{4}$ & $\mathbf{X}_{5}$ & $\mathbf{X}_{6}$ & $\mathbf{X}_{7}$ & $\mathbf{Y}_{1}$ & $\mathbf{Y}_{3}$ & & & & \\
\hline $\begin{array}{c}\text { MIMIC } \\
7-1-3\end{array}$ & $\begin{array}{c}7.19 \\
(1.57)\end{array}$ & $\begin{array}{l}-21.40 \\
(-0.73)\end{array}$ & $\begin{array}{c}-11.95^{*} \\
(-3.78)\end{array}$ & $\begin{array}{c}8.20 \\
(1.95)\end{array}$ & $\begin{array}{l}-1.74 * \\
(-3.64)\end{array}$ & $\begin{array}{c}-27.57 * \\
(-6.87)\end{array}$ & $\begin{array}{l}5.89 * \\
(2.56)\end{array}$ & $\begin{array}{c}0.00089 \\
(0.15)\end{array}$ & $\begin{array}{c}0.054 \\
(1.84)\end{array}$ & $\begin{array}{l}24.53+ \\
(0.079)\end{array}$ & $\begin{array}{l}0.182+ \\
(0.079)\end{array}$ & 0.19 & 16 \\
\hline $\begin{array}{c}\text { MIMIC } \\
6-1-3 a\end{array}$ & - & $\begin{array}{c}-5.59 \\
(-0.21)\end{array}$ & $\begin{array}{c}-13.99 * \\
(-4.38)\end{array}$ & $\begin{array}{l}13.68 * \\
(4.35)\end{array}$ & $\begin{array}{l}-2.30 * \\
(-5.42)\end{array}$ & $\begin{array}{l}-25.80 * \\
(-6.31)\end{array}$ & $\begin{array}{l}3.98 * \\
(2.09)\end{array}$ & $\begin{array}{r}0.0027 \\
(0.43)\end{array}$ & $\begin{array}{l}-0.013 \\
(-0.27)\end{array}$ & $\begin{array}{l}17.14+ \\
(0.193)\end{array}$ & $\begin{array}{l}0.14+ \\
(0.22)\end{array}$ & 0.27 & 13 \\
\hline $\begin{array}{c}\text { MIMIC } \\
6-1-3 b\end{array}$ & $\begin{array}{c}5.71 \\
(1.37)\end{array}$ & - & $\begin{array}{c}-12.57 * \\
(-4.09)\end{array}$ & $\begin{array}{c}10.17 * \\
(3.15)\end{array}$ & $\begin{array}{l}-1.72 * \\
(-3.56)\end{array}$ & $\begin{array}{l}-29.24 * \\
(-8.62)\end{array}$ & $\begin{array}{l}5.15^{*} \\
(2.45)\end{array}$ & $\begin{array}{c}0.0012 \\
(0.21)\end{array}$ & $\begin{array}{c}0.054 \\
(1.82)\end{array}$ & $\begin{array}{c}24.06 \\
(0.031)\end{array}$ & $\begin{array}{c}0.23 \\
(0.040)\end{array}$ & 0.13 & 13 \\
\hline $\begin{array}{c}\text { MIMIC } \\
6-1-2 \mathrm{a}\end{array}$ & - & $\begin{array}{c}-1.29 \\
(-0.047)\end{array}$ & $\begin{array}{c}-12.79 * \\
(-3.86)\end{array}$ & $\begin{array}{l}12.79 * \\
(3.92)\end{array}$ & $\begin{array}{l}-2.12 * \\
(-4.81)\end{array}$ & $\begin{array}{l}-27.66 * \\
(-6.50)\end{array}$ & $\begin{array}{c}3.78 \\
(1.92)\end{array}$ & - & $\begin{array}{c}0.051 \\
(1.68)\end{array}$ & $\begin{array}{l}6.62+ \\
(0.35)\end{array}$ & $\begin{array}{c}0.081+ \\
(0.38)\end{array}$ & 0.44 & 6 \\
\hline $\begin{array}{c}\text { MIMIC } \\
6-1-2 b\end{array}$ & - & $\begin{array}{c}-1.48 \\
(-0.053)\end{array}$ & $\begin{array}{c}-13.60 * \\
(-4.08)\end{array}$ & $\begin{array}{l}13.25 * \\
(4.04)\end{array}$ & $\begin{array}{l}-2.22 * \\
(-5.00)\end{array}$ & $\begin{array}{l}-27.30 * \\
(-6.40)\end{array}$ & $\begin{array}{c}3.87 \\
(1.95)\end{array}$ & $\begin{array}{c}0.00052 \\
(0.089)\end{array}$ & - & $\begin{array}{l}10.12+ \\
(0.12)\end{array}$ & $\begin{array}{c}0.207+ \\
(0.14)\end{array}$ & 0.18 & 6 \\
\hline $\begin{array}{c}\text { MIMIC } \\
5-1-3 a\end{array}$ & - & - & $\begin{array}{c}-12.66^{*} \\
(-3.63)\end{array}$ & $\begin{array}{c}12.49 * \\
(14.11)\end{array}$ & $\begin{array}{l}-2.10 * \\
(-4.60)\end{array}$ & $\begin{array}{l}-29.51 * \\
(-7.79)\end{array}$ & $\begin{array}{c}3.81 \\
(1.80)\end{array}$ & $\begin{array}{c}0.0022 \\
(0.37)\end{array}$ & $\begin{array}{c}0.056 \\
(1.51)\end{array}$ & $\begin{array}{c}15.87+ \\
(0.15)\end{array}$ & $\begin{array}{l}0.17+ \\
(0.17)\end{array}$ & 0.26 & 11 \\
\hline $\begin{array}{c}\text { MIMIC } \\
5-1-3 b\end{array}$ & - & $\begin{array}{l}12.72 \\
(0.37)\end{array}$ & $\begin{array}{l}-7.98 * \\
(-2.56)\end{array}$ & $\begin{array}{l}13.67 * \\
(3.40)\end{array}$ & $\begin{array}{l}-1.72 * \\
(-3.25)\end{array}$ & $\begin{array}{l}-28.62 * \\
(-5.33)\end{array}$ & - & $\begin{array}{c}0.00013 \\
(0.020)\end{array}$ & $\begin{array}{c}0.050 \\
(1.37)\end{array}$ & $\begin{array}{c}19.97 \\
(0.046)\end{array}$ & $\begin{array}{c}0.23+ \\
(0.057)\end{array}$ & 0.14 & 11 \\
\hline $\begin{array}{c}\text { MIMIC } \\
5-1-3 c\end{array}$ & $\begin{array}{c}0.89 \\
(0.20)\end{array}$ & - & $\begin{array}{l}-7.04 * \\
(-2.61)\end{array}$ & $\begin{array}{l}12.92^{*} \\
(3.71)\end{array}$ & $\begin{array}{l}-1.73 * \\
(-3.01)\end{array}$ & $\begin{array}{l}-28.72 * \\
(-6.98)\end{array}$ & - & $\begin{array}{c}0.0022 \\
(0.35)\end{array}$ & $\begin{array}{c}0.056 \\
(1.63)\end{array}$ & $\begin{array}{c}23.28 \\
(0.016)\end{array}$ & $\begin{array}{c}0.26 \\
(0.021)\end{array}$ & 0.13 & 11 \\
\hline $\begin{array}{c}\text { MIMIC } \\
5-1-2 \mathrm{a}\end{array}$ & - & - & $\begin{array}{c}-12.83 * \\
(-4.00)\end{array}$ & $\begin{array}{l}12.87 * \\
(4.68)\end{array}$ & $\begin{array}{l}-2.12 * \\
(-5.04)\end{array}$ & $\begin{array}{c}-27.78 * \\
(-8.26)\end{array}$ & $\begin{array}{l}3.76^{*} \\
(1.97)\end{array}$ & - & $\begin{array}{c}0.051 \\
(1.68)\end{array}$ & $\begin{array}{l}6.62+ \\
(0.25)\end{array}$ & $\begin{array}{c}0.142+ \\
(0.27)\end{array}$ & 0.41 & 5 \\
\hline $\begin{array}{c}\text { MIMIC } \\
5-1-2 b\end{array}$ & - & - & $\begin{array}{c}-13.64 * \\
(-4.22)\end{array}$ & $\begin{array}{l}13.34 * \\
(4.82)\end{array}$ & $\begin{array}{l}-2.21 * \\
(-5.24)\end{array}$ & $\begin{array}{l}-27.44 * \\
(-8.17)\end{array}$ & $\begin{array}{l}3.84 * \\
(1.99)\end{array}$ & $\begin{array}{c}0.00054 \\
(0.093)\end{array}$ & - & $\begin{array}{c}9.66+ \\
(0.085)\end{array}$ & $\begin{array}{l}0.241+ \\
(0.098)\end{array}$ & 0.18 & 9 \\
\hline $\begin{array}{c}\text { MIMIC } \\
5-1-2 c\end{array}$ & - & $\begin{array}{l}11.59 \\
(0.39)\end{array}$ & $\begin{array}{l}-8.23 * \\
(-3.05)\end{array}$ & $\begin{array}{l}14.28 * \\
(4.10)\end{array}$ & $\begin{array}{l}-1.80 * \\
(-3.91)\end{array}$ & $\begin{array}{c}-29.14 * \\
(-6.24)\end{array}$ & - & - & $\begin{array}{c}0.054 \\
(1.73)\end{array}$ & $\begin{array}{l}6.58+ \\
(0.25)\end{array}$ & $\begin{array}{c}0.141+ \\
(0.28)\end{array}$ & 0.41 & 5 \\
\hline $\begin{array}{c}\text { MIMIC } \\
5-1-2 d\end{array}$ & - & $\begin{array}{l}11.98 \\
(0.40)\end{array}$ & $\begin{array}{l}-9.13 * \\
(-3.35)\end{array}$ & $\begin{array}{l}14.89 * \\
(4.24)\end{array}$ & $\begin{array}{l}-1.91 * \\
(-4.12)\end{array}$ & $\begin{array}{l}-28.84 * \\
(-6.17)\end{array}$ & - & $\begin{array}{c}0.0012 \\
(0.21)\end{array}$ & - & $\begin{array}{l}10.19+ \\
(0.070)\end{array}$ & $\begin{array}{l}0.255+ \\
(0.081)\end{array}$ & 0.14 & 5 \\
\hline $\begin{array}{c}\text { MIMIC } \\
4-1-3\end{array}$ & - & - & $\begin{array}{l}-7.36 * \\
(-3.33)\end{array}$ & $\begin{array}{l}13.30 * \\
(4.38)\end{array}$ & $\begin{array}{l}-1.80 * \\
(-4.02)\end{array}$ & $\begin{array}{l}-28.20 * \\
(-7.47)\end{array}$ & - & $\begin{array}{c}0.0020 \\
(0.34)\end{array}$ & $\begin{array}{c}0.055 \\
(1.77)\end{array}$ & $\begin{array}{c}22.78 \\
(0.007)\end{array}$ & $\begin{array}{c}0.31 \\
(0.0091)\end{array}$ & 0.10 & 9 \\
\hline
\end{tabular}




\begin{tabular}{|c|c|c|c|c|c|c|c|c|c|c|c|c|c|}
\hline $\begin{array}{c}\text { MIMIC } \\
4-1-2 a\end{array}$ & - & - & $\begin{array}{l}-7.62 * \\
(-3.45)\end{array}$ & $\begin{array}{l}13.59 * \\
(4.49)\end{array}$ & $\begin{array}{l}-1.84 * \\
(-4.11)\end{array}$ & $\begin{array}{c}-28.06 * \\
(-7.46)\end{array}$ & - & - & $\begin{array}{l}0.054 \\
(1.73)\end{array}$ & $\begin{array}{l}6.58+ \\
(0.16)\end{array}$ & $\begin{array}{c}0.201+ \\
(0.18)\end{array}$ & 0.37 & 4 \\
\hline $\begin{array}{c}\text { MIMIC } \\
4-1-2 b\end{array}$ & - & - & $\begin{array}{l}-8.52 * \\
(-3.82)\end{array}$ & $\begin{array}{l}14.21 * \\
(4.66)\end{array}$ & $\begin{array}{l}-1.96 * \\
(-4.34)\end{array}$ & $\begin{array}{c}-27.72 * \\
(-7.39)\end{array}$ & - & $\begin{array}{c}0.0011 \\
(0.18)\end{array}$ & - & $\begin{array}{c}9.65 \\
(0.047)\end{array}$ & $\begin{array}{c}0.297+ \\
(0.055)\end{array}$ & 0.12 & 4 \\
\hline
\end{tabular}

P-value for Test of Close Fit (RMSE <0.05); sign + shows a good adjustment (p-value>0.05).

AGFI is adjusted coefficient of determination. It ranges over the interval $[0,1]$.

The number of degrees of freedom determined as follows: $0.5(q+p)(q+p+1)$ - $t$, where q-number of indicators, causes $p$-number, t-number free parameters.

In parentheses is the value of t-statistic, it is desirable that the absolute value ABS (t-statistic)> 1.96; fulfilment of this condition is marked with*.

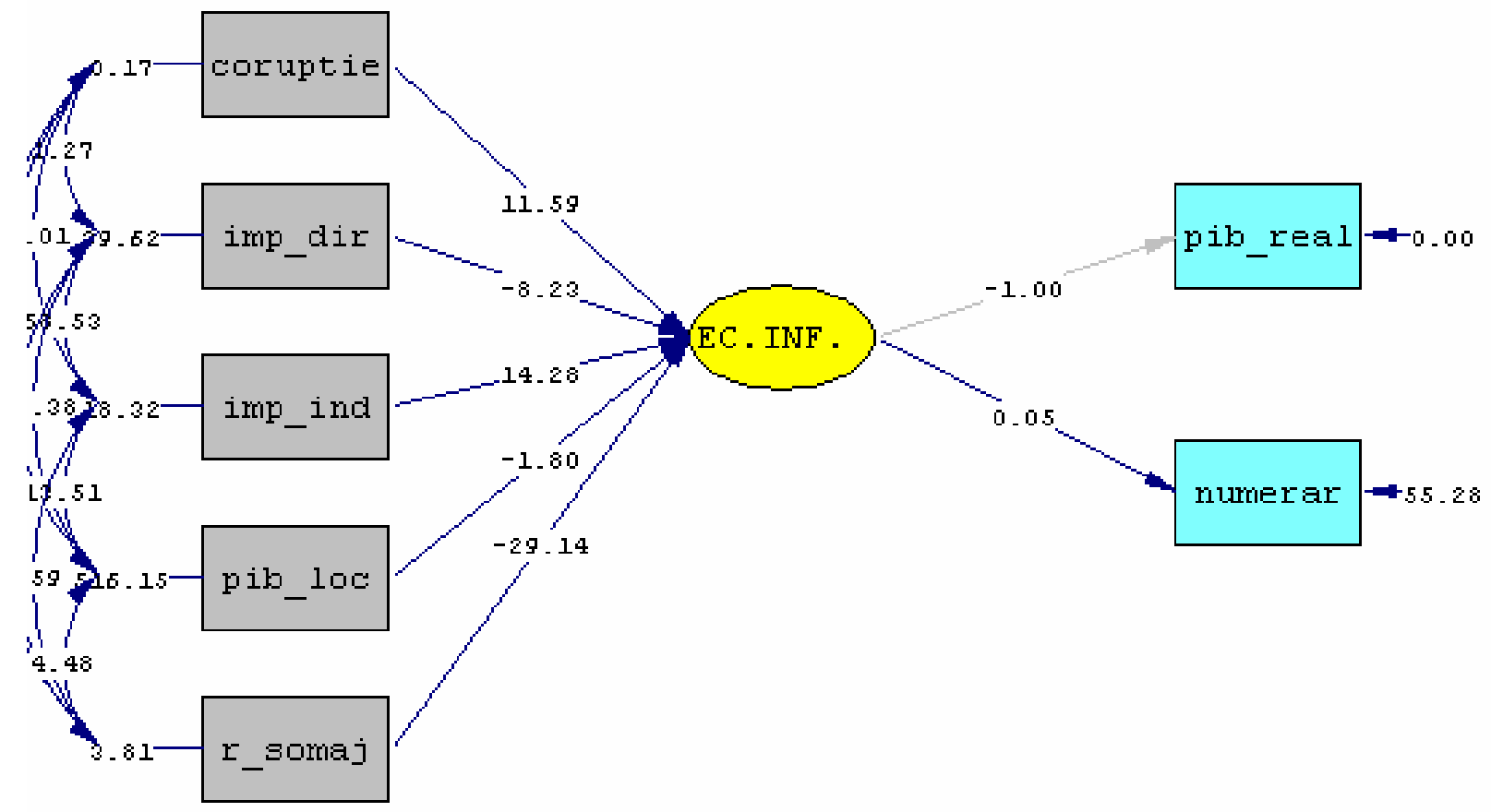

Figure no. 3.MIMIC 5-1-2c 
Underground economy is calibrated according to the amount recorded in 1990, the base year. This value was taken from Professor Fr. Schneider studies, and represents $18 \%$ of official GDP (Schneider, 2007).

Structural equation model was used to obtain an index time series for the underground economy. Because all variables are expressed as differences of first order, to compute the latent variable by multiplying the structural coefficients for the series (unfiltered) is equivalent with processing related index changes by multiplying the coefficients for one of the causes of gaps, and then integrate them. Estimated evolution of Romania underground economy as share of official GDP is shown in Figure no. 4.

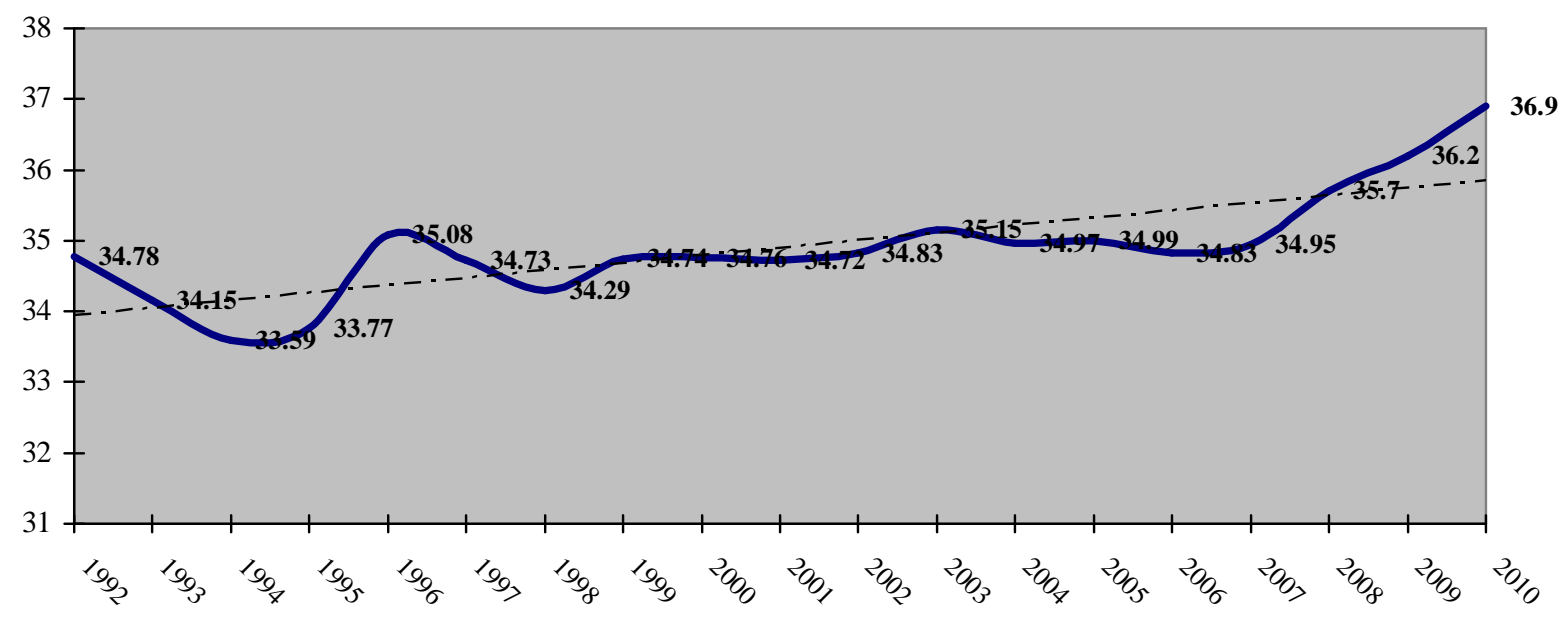

Figure no.4. Estimated evolution of Romania underground economy as share of official GDP

The size of underground economy in Romania for the period under review varies around an average of $34.8 \%$ as share of official GDP, lower values recording in 1994-1995. There is a relative constancy in this indicator dynamics, but its performance is certainly upward. Based on the estimated size we planned our economy in the near future, pointing calculations value for underground economy to $37.5 \%$ of official GDP in $2010-2011$.

\section{Concluding Remarks and Policy Perspectives}

According to the results presented in this paper the relative size of the underground economy in Romania increased over time. The Romanian underground economy causes consists primarily of taxes, changes in official output per capita, unemployment and bureaucracy. Degradation or worsening of these indicators evolution will cause an increase of reached level more than $40 \%$ of official GDP in the near future.

Given the relatively small number of variables (including indicators) used in this model, it is possible to improve the estimates obtained and the resulting changes could be major.

Any confirmation of these results would have important implications for controlling the size of the Romanian underground economy via fiscal policy. Finally, the findings in this paper suggest that both the size and the scope of a country's underground economy may serve as an indicator for a country specific economic and social reform agenda, which in turn would allow for constructing a development reform index. In such an index the scope of the underground economy could well serve as a mirror imaged blueprint for the type of reforms need in a country, while its relative size and its growth rate would hint at how urgent these reforms are. 


\section{References}

1. Breusch T., 2005. Estimating the Underground Economy usind MIMIC Models, The Australian National University, Canberra, ACT 0200.

2. Dell'Anno R., Gómez M., Pardo Á. A., 2004. Shadow Economy in three very different Countries: France, Spain and Greece. A MIMIC Approach, www.unisa.it, WP April.

3. Ene C. M., Mitroi A., 2008. Two Sides of the MIMIC Model of the Underground Economy, Econophysics, New Economics \& Complexity International Conference, ENEC Working Papers CD, May 2008, ISBN 978-973-8128-94-1.

4. Ene C. M., 2010. Tax Evasion Dynamics in Romania Reflected by Fiscal Inspection Activities, Romanian Journal of Economics, 2010(XX), Volume 30, Issue 1(39), ISSN 1220-5567;

5. Enste D., Schneider F., 1998. Increasing Shadow Economies All Over the World - Fiction or Reality? A Survey of the Global Evidence of their Size and of their Impact from 1970 to 1995, IZA Discussion Paper No.26, December.

6. Giles David E.A., 1999, Modelling the Hidden Economy and the Tax-Gap in New Zealand, Feb., http://web.uvic.ca/econ/economet_he.html;

7. Giles David E.A. \& Tedds Lindsay M., 2002, Modelling the Underground Economies in Canada and New Zealand: A Comparative Analysis, Econometrics Working Paper EWP0003, April.

8. Schneider F., 2005, Shadow Economies of 145 Countries all over the World: Estimation Results over the Period 1999 to 2003, Johannes Kepler University of Linz, WP on www.econ.jkku.at/Schneider.

9. Schneider F., Enste Dominik H., 2002, The Shadow Economy. An International Survey, Cambridge University Press.

10. Schneider F., 2007, Shadow Economies and Corruption All Over the World: New Estimates for 145 Countries, Economics E-Journal, No.2007-9, July 24.

11.Tedds Lindsay M., 2005, The Underground Economy in Canada, in Size, Causes and Consequences of the Underground Economy. An International Perspective, Edited by Christopher Bajada and Friedrich Schneider, Ashgate Publishing Ltd, 2005. 